\title{
Changes in the configurations of corporate governance and agency relationship: a longitudinal analysis in a privately held company
}

\author{
FABRICIO BOMTEMPO OLIVEIRA ${ }^{1}$ \\ JOAQUIM RUBENS FONTES FILHO ${ }^{1}$
}

\author{
${ }^{1}$ Fundação Getulio Vargas (FGV EBAPE) / Escola Brasileira de Administração Pública e de EMpresas, Rio de JaneIRo - RJ, Brazil
}

\begin{abstract}
This article aims to identify the changes in corporate governance associated with the life cycle of companies. It is guided by the research problem of understanding what effects the maturity of the business has on its ownership structure, corporate relations, and other governance configurations. The study used longitudinal analysis of the changes that occurred in Transportadora Brasileira Gasoduto Bolivia-Brasil SA (TBG), a privately held company controlled by Petrobras Logística de Gás, with the participation of several state and private partners. The data were collected through document analysis and interviews with executives. The results identified the relationship between the stages of the business and the characteristics of the investors, ranging from an initial moment built around energy companies specialized in the business to the maturity phase when the investment became interesting to capitalist partners interested in financial results. In addition, planning before capital consolidation, the existence of a financing structure, clear criteria for selecting partners, and the presence of a second relevant shareholder, mitigates any problems of abuse of power or non-compliance with established rules, contributing to preserving the relationship between shareholders over time and the sustainability of corporate agreements. The study contributes to a new perspective on the analysis of corporate governance, considering necessary changes and adaptations over time and reflections on the corporate structures and priorities of the governance actors.
\end{abstract}

Keywords: Agency relations. Corporate governance. Ownership structure. Longitudinal analysis. Company life cycle.

\section{Mudanças nas configurações de governança corporativa e relações de agência: uma análise longitudinal em empresa de capital fechado}

\section{Resumo}

Este artigo tem como objetivo identificar as mudanças na governança corporativa associadas a ao ciclo de vida das empresas, orientado pelo problema de pesquisa de compreender quais efeitos a maturidade do negócio produz na sua estrutura de propriedade, relações societárias e outras configurações de governança. Como procedimento metodológico foi realizada análise longitudinal das mudanças ocorridas na Transportadora Brasileira Gasoduto Bolívia-Brasil SA (TBG), empresa de capital fechado controlada pela Petrobras Logística de Gás, com a participação de vários parceiros estatais e privados. As informações foram coletadas a partir de análise documental e entrevistas com executivos que participaram de sua administração. Como resultado, foi possível identificar a relação dos estágios do negócio às características dos investidores, variando desde um momento inicial construído em torno de empresas de energia especialistas no negócio, à fase de maturidade, quando o investimento se tornou interessante a sócios capitalistas, mais interessados nos resultados financeiros. Além disso, o planejamento antes da consolidação de capital, a existência de uma estrutura de financiamento, de critérios claros para selecionar os parceiros e a presença de um segundo acionista relevante, mitigando eventuais problemas de abuso de poder ou não observância a regras estabelecidas, contribuíram para preservar a relação entre os sócios ao longo do tempo e a sustentabilidade dos acordos societários. Com a abordagem longitudinal utilizada, o estudo visa contribuir para uma nova perspectiva de análise das práticas de governança corporativa, considerando suas mudanças e adaptações necessárias ao longo do tempo, e reflexos sobre as estruturas societárias e prioridades dos atores da governança.

Palavras-chave: Relações de agência. Governança corporativa. Estrutura de propriedade. Análise longitudinal. Ciclo de vida da empresa.

\section{Cambios en las configuraciones de gobierno corporativo y relación de agencia: un análisis longitudinal en una empresa de capital cerrado \\ Resumen}

Este artículo tiene como objetivo identificar los cambios en el gobierno corporativo asociados con el ciclo de vida de las empresas, guiado por el problema de investigación de comprender qué efectos tiene la madurez del negocio en su estructura de propiedad, relaciones societarias y otras configuraciones de gobierno. El estudio utilizó, como procedimiento metodológico, un análisis longitudinal de los cambios ocurridos en Transportadora Brasileira Gasoduto Bolívia-Brasil SA (TBG), empresa privada controlada por Petrobras Logística de Gás, con la participación de varios socios estatales y privados. La información fue recolectada a través del análisis de documentos y entrevistas con ejecutivos que participaron en su gestión. Como resultado, fue posible identificar la relación entre las etapas del negocio y las características de los inversionistas. Los análisis permitieron relacionar las etapas del negocio con las características de los inversores, que van desde un momento inicial, construido alrededor de empresas energéticas especializadas en el negocio, hasta la fase de madurez, cuando la inversión se vuelve interesante para los socios capitalistas, más interesados en los resultados financieros. Además, la planificación previa a la consolidación de capital, la existencia de una estructura de financiación, de criterios claros de selección de socios y la presencia de un segundo accionista relevante, para mitigar eventuales problemas de abuso de poder o incumplimiento de las reglas establecidas, contribuyeron a preservar la relación entre socios a lo largo del tiempo y la sostenibilidad de los acuerdos societarios. Con el enfoque longitudinal utilizado, el estudio se propone contribuir a una nueva perspectiva de análisis de las prácticas de gobierno corporativo, considerando sus cambios y adaptaciones necesarias con el tiempo, y reflexiones sobre las estructuras corporativas y prioridades de los actores del gobierno corporativo.

Palabras clave: Relaciones de agencia. Gobierno corporativo. Estructura de propiedad. Análisis longitudinal. Ciclo de vida de la empresa. 


\section{INTRODUCTION}

The development of corporate governance has been marked by the quest for minimising conflicts between shareholders and executives. Since the seminal work of Berle and Means (1932), discussing the separation of ownership and control in American companies, the tension between these two groups of stakeholders that form the typical agency problem (type I) has led studies and models on governance to work to reduce the managerial expropriation and creating adequate incentives to achieve the maximisation of business return.

One case representing a landmark in the conflict between shareholders and management interests is Texaco, in 1984. The company's executives, knowing that a group of investors were willing to purchase stocks to increase their ownership and take over the company's control, decided to use the company's resources to buy the investors' stocks paying US\$137 million premium over the market price, an option that was not given to the other shareholders. The executives avoided losing control of the company, without involving the other shareholders in the decision making (Monks \& Minow, 2011). This case showed that executives were more concerned about holding their positions than with shareholders' interests.

However, the magnitude of the principal-agent conflicts varies in a cross-sectional way among companies according to the ability of managers and shareholders to exercise their preferences; the complexity of the company; and the various characteristics of the industry. Therefore, agency problems are different in each firm and require different governance structures (Dey, 2008). Especially in contexts where the principal-principal relationship is predominant (because of concentrated ownership with an individual shareholder or group, where conflicts move to the relationship between the controlling and the minority shareholders), the idiosyncrasies of the companies and the different relationships between controlling shareholders, minority shareholders, and management result in distinct governance configuration that cannot be understood by cross-sectional modelling.

Also, the studies between firms reduce or even disregard the singularities of the companies and their external and internal relationships, as well as the tensions between stakeholders and the broader power games that characterise corporate governance (Licht, 2011). The static perspective in the study of governance considered is not always compatible with the transformations and adjustments that companies go through in processes of business rearrangement, changes in the shareholding structure, or to what extent governance evolves along the corporate life-cycle (O'Connor \& Byrne, 2015a). This perspective does not allow understanding the effect that endogenous or exogenous mechanisms, or conditions such as propensity to risk of the players involved in the governance and availability of information, can introduce over time on the dynamics of the company's governance, insufficiency that can aggravate problems of collective decision, free riding, asymmetries of information or moral hazard. In this sense, Filatotchev, Toms and Wright (2006, p. 257) remarks that "Much attention has been focused on the largest mature companies listed on a stock market, concentrating on the static theorising of the principal-agent perspective. Less attention has therefore been paid to the change processes in governance and variations in the principal-agent relationship through the full life cycle of the firm from inception to maturity".

Over time, a change in the ownership structure, for example, brings about new conflicts, mainly due to changing expectations or interests between the parties, which can affect the quality of the shareholders or board decisions, and aggravate the principal-principal problem. The agency theory does not address the effects of these changes on the nature of the principal over agency problems, particularly for three reasons: a) for not bringing a dynamic view of the principal-agent relationship; b) for considering the principal as a single actor or homogeneous set aligned around the goal of maximization of companies' value; and c) for putting forward its propositions mainly to avoid the risks associated with the behaviour of the agent.

Even if the ownership structure of a company remains the same, the owners' interests may change, which is a significant event particularly in contexts of concentrated ownership, due to the greater influence of the controllers. These interests may change in several situations, for example when an investor needs to increase their dividends and imposes a disinvestment strategy; when a parent company is in a controlling position and changes its strategy in the business portfolio where the investee is included; when the state control the company, and a change of government occurs; as well as countless other possibilities. 
However, despite this recognition regarding the variation of the agency conflicts over time, the studies on these conflicts and their solutions, internally within the companies, following a temporal, longitudinal perspective, are rare (O'Connor \& Byrne, 2015a).

This study aims to contribute to the current literature on the topic seeking, as a research problem, to understand the relationships between changes in the life cycle of companies that influence their corporate configurations and structures, their governance arrangements and the way in which agency problems and principal-principal issues are handled. It aims to describe how the various conflicts inherent to governance change over time, particularly with the change in the group of relevant shareholders, or the change in the shareholders' interests regarding the objectives and results of the business. Following the premise that the expectation of maximizing company value is not hegemonic to all shareholders (Jensen, 2010), investors can direct resources to a company to access critical resources and carry out synergies, increase market power or seize opportunities to improve the company's efficiency and results, generating additional revenue (Weitzen \& McCarthy, 2011).

In order to expand the understanding of how the relationships between owners that affect governance are constructed, this study identifies the evolution of these relationships and their effects on governance over time. As a methodology, this study adopts a longitudinal analysis of the transformations in the ownership and governance practices of a closed company. The company studied presents the main characteristics necessary to carry out the analysis, such as changes in ownership, participation of the state, changes in the nature of the business and in the performance expectations, and is less subject to exogenous pressures of the market. The company observed is the Transportadora Brasileira Gasoduto Bolivia-Brasil (TBG), controlled by Petrobras Logística de Gás S.A. TBG was established in 1997 to transport gas from Bolivia to Brazilian consumer markets, which also involved several private and state partners. TBG owns and operates the part located in Brazilian territory of the Bolivia-Brazil Gas Pipeline. The various ownership changes and strategic reconfigurations that TBG went through in the years following its foundation motivated the choice of this company for the study.

In this sense, adapting the line followed in a previous study by Thomsen (2004), we particularly examine changes throughout the company's life cycle in three governance mechanisms: its ownership structure, the composition of the board and the influence of shareholders.

\section{THEORETICAL FRAMEWORK}

The agency theory discusses the problems resulting from the separation of ownership and management (agency problems), and it is the dominant theoretical perspective applied to corporate governance studies. The basic premise is that if both parties in a principal-agent relationship seek to maximise their utility function, the agent will not always act in the best interest of the principal. The principal may limit divergences from their interests by establishing incentives for the agent, and by incurring monitoring costs to limit agent's aberrant activities (Jensen \& Meckling, 1976).

Despite the predominance of analysis of static contexts and the use of cross-sectional data, an increasing amount of the literature discusses the limitations of this modelling because they do not reflect time-related interdependencies and present severe limitations on endogeneity and causality problems (Filatotchev \& Wright, 2017).

Previous studies on the topic have observed that organizational culture differs according to enterprise life cycle stage (Belak, 2016), that corporate governance parameters are linked to strategic "thresholds" or transitions stages along the firm's life-cycle (Filatotchev \& Wright, 2006). Mature firms tend to practice better overall corporate governance, mainly by strengthening discipline and independence, while young firms tend to be more transparent and responsible $\left(\mathrm{O}^{\prime} \mathrm{Connor} \&\right.$ Byrne, 2015a), although governance creates more value for young or "immature" firms than for "mature" ones (O'Connor \& Byrne, 2015b).

Other factors, such as changes in the actors' propensity to risk (Cuevas-Rodríguez, Gomez-Mejia \& Wiseman, 2012), the evolution of internal relations between shareholders and the control of managerial opportunism (Shen, 2003), or the changes brought about by deregulation processes, which reduce incentives for shareholders to monitor managers by introducing the 
disciplinary power of government agencies (Bongjin, 2002; Walsh \& Seward, 1990), also impose requirements for reviewing governance structures and practices over time.

Aguilera, Florackis and Kim (2016) propose a new research agenda on the subject, incorporating, as well as the agent-principal, the idea of principal-principal conflicts. The authors recognise that different owners can have different preferences and time horizons, resulting in different conflicts of interest. The research on principal-principal conflicts has recently increased, accumulating knowledge and presenting new proposals.

When focusing on the principal and agency relationship, other issues emerge as relationships and identities are analysed according to their changes over time. Licht (2011) proposes a different perspective on corporate governance problems, in addition to the principal-agent relationship. For the author, corporate governance is, above all, a matter of power and how it is allocated in the company. This perspective refers to the numerous simplifications brought about by agency theory, which considers the principal as a single, homogeneous and continuous entity, and does not observe other influential actors in the configuration of company strategies.

O'Connor and Byrne (2015a) studied companies in 21 emerging economies, observing the relationship between corporate governance practices and the company's lifecycle. The authors found that mature companies tend to follow the best governance practices, but companies tend to be more accountable when they are younger. Their research indicates that the functions of strategy, monitoring, and control have a distinct relevance over the companies' lifecycle.

Filatotchev et al. (2006) identified different roles of the corporate governance in different stages of the companies' lifecycle, pointing out that an appropriate change of stage is accompanied by rebalancing in the governance structure and roles.

Looking at the broader governance structures in franchising models, Mitsuhashi, Shane and Sine (2008) note that static explanations for the organisational form are insufficient to adequately explain the choices for specific types of governance structures. According to the authors, this happens because organisational structure is path dependent, i.e., depends on previous experiences and actions, and, therefore, when first experiences and actions lead the organisations in one direction, it is difficult to change this path. The authors point out that the form of organisational governance is shaped by dynamic historical processes, such as the organisational momentum. In short, "history matters!" (Mitsuhashi et al., 2008, p. 1135).

However, the search for alignment among shareholders of closed companies poses specific challenges, often different from those observed in publicly held corporations, due to the lack of liquidity of the shares, less external control by market agents, and less transparency regarding disclosing information. These issues are manifested especially in situations where the company is owned partially by other companies and is subject to their interests, operating as a joint venture.

Moll (2005) points out that the search for alignment among shareholders in closed companies presents specific challenges since they are characterised by a small number of shareholders, lack of a market to trade shares, and significant shareholder participation in the company's management. The typical problems in these companies - differently from what is observed in publicly held companies - refer to conditions leading to minority shareholders oppression due to the absence of exit rights; the rule of corporate governance based on the majority's will; deference to the business judgment role; and lack of adequate planning.

Shareholder's exit rights, mainly associated with the existence of a market to trade shares, are useful in two main respects. First, they allow shareholders to liquidate their investment and recover the value of the invested capital. Second, the threat of exit in large numbers tends to restrict managers to take actions that detract from the shareholders' interests. The absence of exit rights may lead to oppressive conduct such as the appropriation of minority shareholders' investment. This absence in closed companies is perceived in many ways as minorities find themselves unable to sell their shares, to demand that another shareholder purchases the shares, or are unable to cause the company's dissolution. 
Moll (2005) argues that even in the absence of exit rights the oppression would not occur if the minority shareholders could block the actions of the controlling shareholders that may jeopardise their interest, i.e., if the minority has veto power in decisions that affect their interests. Usually, the controlling shareholder has the power to elect a majority of the representatives on the Board of Directors, and there is a tendency for the Directors to respond to the wishes of those who appointed them. If decisions within the board are made by a simple majority, even by appointing representatives, minority shareholders are not able to avoid oppressive conduct. One mechanism minority have, to avoid the principle of "majority rule", is to require that board decision-making processes consider a voting system such as the adoption of the need for a supermajority.

Finally, the lack of planning before committing capital is one of the main problems in the relationship of shareholders of closed companies, especially affecting minority rights. Safeguard clauses such as supermajority provisions, buy-and-sell agreements, and labour contracts, can be negotiated with the controlling shareholders as preconditions for company formation. However, investors in closed corporations usually fail to demand these types of protection for reasons ranging from the existence of personal relationships or an initial atmosphere of mutual trust, or to the fact that shareholders are often not sophisticated in legal and business terms (Moll, 2005).

\section{METHODOLOGY}

In order to understand the evolution of the relationships between owners and their effects on governance practices and structures, the research adopted a single longitudinal analysis (Miller \& Friesen, 1984; Thomsen, 2004). It is an exploratory study carried out at the TBG, a closed corporation controlled by Petrobras Logística de Gás S.A. but formed with several partners in its ownership structure. TBG was chosen due to the intense reconfiguration of the shareholding structure throughout its history, as a result of the evolution of the business environment in Brazil and Bolivia, as well as shareholders strategic repositioning.

The study was conducted in three parts. First, a documentary research was carried out collecting and analysing material publicly disclosed by the company, describing its processes and considerations of shareholders and other organisations such as the World Bank and other governments, to understand the changes that occurred in the business environment, shareholders' strategic objectives, shareholding structure, and the governance mechanisms implemented by TBG. Next, field research was carried out, supported by semi-structured interviews with managers who experienced the company's governance at different times in its history, based on the issues raised in the theoretical background presented here. Finally, the results were analysed, observed in the light of the theoretical background, presenting a report with analysis and findings.

Fifteen face-to-face interviews were conducted with current and previous TBG managers, and two interviews with managers of the controlling company that performed important functions for TBG's business. All interviews were conducted during the second semester of 2014. The sample obtained was considered sufficient, since it included almost all the main executives (Superintendent Directors) and a considerable number of Directors from different periods of the company's history. Also, it was possible to observe saturation in responses (Fusch \& Ness, 2015; Thiry-Cherques, 2009).

\section{The trajectory of the Transportadora Brasileira Gasoduto Bolivia-Brasil (TBG)}

The construction of a gas pipeline bringing Bolivian gas to Brazilian markets represented the convergence of two different interests. For Brazil, the pipeline represented the access to a new source of energy and the possibility of diversifying its energy matrix, while for Bolivia it was the materialization of the only opportunity of sustained economic growth of their economy, as it allowed their natural gas reserves to be integrated with a large potential consumer market (Torres, 2002). However, aligning actors (investors) with significantly unbalanced financial capabilities and different national projects around a long-term investment project has brought unique governance challenges, which have become more complex with the inclusion of other partners and interests in the business. 
In the early years of the negotiations that resulted in the establishment of TBG, between 1994 and 1997, the partners and future shareholders sought to harmonise their interests and align towards the goal of enabling the construction of the gas pipeline for the import of natural gas from Bolivia. Initially, the negotiations were held between the companies YPFB (Yacimientos Petroliferos Fiscales Bolivianos) and Petrobras, the latter led, in response to the Brazilian government's interest, to engage in increasing the participation of gas in the national energy matrix.

The original intention of the Brazilian federal government and the World Bank (one of the main financiers of the project), was that the investments in the pipeline were mostly private. However, the uncertainties associated with the project, especially about the availability of gas reserves in Bolivia; the existence of the consumer market on the Brazilian side; and regulatory uncertainties, inhibited private entrepreneurs from taking the lead in the natural gas transportation project. This context pushed Petrobras to take the lead and present the guarantees for the business, with the support of the Brazilian federal government.

The representatives of the Brazilian federal government at the time, contrary to the state control of the project, were convinced that there would be no other alternative to make it viable. The decision to take the lead in building a 3,000 km pipeline project was greatly criticised by sectors of society and internal areas of the company given the huge risks involved.

The process of selecting the shareholders resulted in the signing of a Memorandum of Understanding (MOU) in 1994 with the BTB Group (formed by the Australian BHP - Broken Hill Proprietary, the American Tenneco, and BG - British Gas). According to one of the interviewees, the French company Total and the American Enron also participated in the selection process.

According to a report published by the World Bank (Law \& De Franco, 1998), the shareholders played an important role in making the financing feasible, given their size and reputation. Tenneco, in particular, for its experience in natural gas transportation projects in the United States, provided relevant knowledge in the elaboration of gas transportation contracts, something that Petrobras did not have at that time.

It is important to remember that before 1997 there was a state monopoly of the activities of the oil and gas industry in Brazil. From that year, after the so-called Oil Law, foreign companies were allowed to settle in Brazil and engage in the exploration, production, transportation, import and sale of oil and gas. Therefore, although there was high regulatory risk because foreign companies were not allowed to operate in this sector in Brazil, the relevance of the domestic market and its growth potential allied to the possibility of associating with a dominant player seemed to be attractive in the eyes of large international groups.

During the first negotiations, contract design played a central role in the relationship between the partners. Several respondents commented that the clauses of shareholder agreements and transportation contracts were thoroughly discussed, with complex discussions that lasted for about a year. Each shareholder targeted a specific goal, and the negotiating environment had representatives who brought the experiences from the legislation of their countries. In the opinion of one of the participants in these meetings and later as a director of TBG, "building a shareholders' agreement that appealed to the representatives of all these parties was a work of art".

According to reports made by three respondents, several safeguards were included in the shareholders' agreement in order to preserve the rights of the parties, resulting in a robust and complex document in their view. One of the interviewees commented that two shareholders' agreements were produced, an agreement involving all shareholders, at the time Gaspetro (Petrobras subsidiary) (51\%), BBPP (previously called BTB) (29\%), Transredes (16\%), Shell (2\%) and Enron (2\%); and a bilateral agreement involving only the two largest partners, Gaspetro and BBPP group. This model of composition with at least one large shareholder besides the controller is aligned with that recommended by Pagano and Roell (1998), as a measure to facilitate the monitoring of the controller, thus reducing agency costs.

In the opinion of six interviewees, the monitoring role carried out by the second largest shareholder, in this case, the BBPP group (29\%) contributed significantly to deepen discussions within the Board of Directors.

Among the most discussed topics, the interviewees pointed out the clauses regarding the reliability guarantees regarding the operation of the pipeline, respecting an international standard, international rules of shareholding structure and information disclosure. According to reports, there was a great concern of companies regarding their brands and the fear that operational failure or negative event related to TBG could impact the image of the parent companies. 
Each shareholder had their motivation to participate in the project and considered the endeavour as an opportunity to secure long-term revenue and represent a platform for growth in their activities in Brazil. In the case of the large multinationals, much more for the second reason than the first because of their small shares and revenues (if compared to their sizes). Some of these corporations were associated in the BBPP group (29\%), which was an interesting strategy because it allowed, on the one hand, power in the approval of relevant matters, on the other, sharing the monitoring costs.

The intensity of the discussions and negotiations resulted in robust contracts that proved to be of great importance at events throughout the company's history. Because there was a gas supply contract signed with Bolivia implying in commitments regarding deadlines, in the opinion of one of the interviewees, Petrobras played a key role so that the negotiations did not lose focus and did not extend sine die.

During the first years of the company (1998-2001), a sensitive issue regarding governance and relationship among shareholders was TBG's debt to Petrobras, referring to the constructions of pipelines. In July 1998, Petrobras and TBG entered into a "Contract of Transfer and Construction Management," according to which Petrobras took over the works using its resources for later reimbursement by TBG. The contracting of Petrobras to carry out the works that began in 1997 was the way found by the shareholders to guarantee completion of the work within the deadline established in the Gas Supply Agreement (GSA), since waiting for financing to finish the construction could impact the schedule. It is worth noting two points: the complexity of the work, involving the relationship with environmental agencies in five Brazilian states and the fact that TBG was newly created and did not have technical staff at that time.

According to one of the interviewees, the association with major international oil companies made the decision-making process in the subsidiary TBG different from that practised, in general, in Petrobras. Topics related to costing and investments required in-depth analyses by the board members. Often additional clarifications were requested, and topics were extracted from the meetings' agenda so that the premises and results could be analysed in detail.

In the case of the investment made in the pipeline, because it was an issue involving one of the shareholders, many clarifications were required by the board members. Due to the nature of the arrangement, the decision was discussed within the Board of Directors, which submitted a proposal for a decision of the Shareholders' Meeting. According to TBG's bylaws, transactions between related parties require the approval of at least $81 \%$ of the votes in the Shareholders' Meeting. As Gaspetro held $51 \%$ and the BBPP group, $29 \%$, in addition to the agreement of these two shareholders, the acceptance of at least one of the other minority shareholders was needed. Therefore, the requirement to achieve $81 \%$ of the votes for matters involving related parties was an effective safeguard to prevent minority exclusion.

According to one of the interviewees, the first years of TBG (during which most of the company's debt with Petrobras was paid) were the years where the greatest divergences between the shareholders appeared. On one side, minority shareholders demanded detailed data and information about the costs of the infrastructure works. On the other, there was a controlling shareholder that was not used to being in a relationship with other owners in a partnership. According to the data collected in the interviews, the first years witnessed a process of trust-building between parties. The clarifications regarding the investments in the pipeline were provided, analysed and the payments approved.

The first three years of TBG's existence was the time where minority shareholders could be more influential, including appointing executives who contributed greatly to the maturity of the company's management, according to several interviewees. An interviewee reported that in the first years, the presence of employees of the minority shareholders that looked for detailed explanations on the operations was frequent. In the interviewee opinion, this frequency was reduced as these representatives realised that the company was operated to the expected standards of excellence.

There were involuntary and voluntary changes in TBG's shareholding structure as shown in Box 1. In the first case, shareholders were replaced due to Enron's bankruptcy and the nationalisation of Transredes, as a consequence of the nationalisation of hydrocarbons' decree in Bolivia in 2006. 
In the case of voluntary changes, shareholders sold their shares for strategic reasons. In the opinion of all interviewees, changes in the shareholding structure over time did not impact the company's governance since the rules governing the relationship between the shareholders were very well established in TBG's bylaws and shareholders' agreement.

\section{Box 1}

\section{TBG: changes in the shareholding structure}

\begin{tabular}{|c|c|c|}
\hline Year & Shareholders & Event \\
\hline 1994 & BTB, BG, Tenneco, BHP & $\begin{array}{l}\text { Selection of the BTB group, formed by BHP, Tenneco and BG to be shareholders } \\
\text { together with the Brazilian Petrobras. }\end{array}$ \\
\hline 1996 & BTB, Tenneco, El Paso & $\begin{array}{l}\text { Merge between Tenneco Energy and El Paso Energy. El Paso takes over Tenneco's } \\
\text { position in the BTB group. The BTB group becomes BBPP Holdings Ltda. }\end{array}$ \\
\hline 1997 & $\begin{array}{l}\text { Transredes, Enron, } \\
\text { Shell and Bolivian } \\
\text { pension funds }\end{array}$ & $\begin{array}{l}\text { The Bolivian private company Transredes is created to operate for } 40 \text { years the } \\
\text { monopoly of hydrocarbon transportation in Bolivia. Transredes' shareholding } \\
\text { structure was: Shell (25\%), Enron, (25\%) and Bolivian pension funds (50\%). }\end{array}$ \\
\hline 1997 & TBG & $\begin{array}{l}\text { Creation of TBG, with the following shareholding structure: Gaspetro (51\%), } \\
\text { BBPP }(29 \%) \text {, Transredes (29\%), Enron (4\%) and Shell (4\%). }\end{array}$ \\
\hline 2001 & BBPP, BHP and Total & Total purchases the BHP's shares in the BBPP, acquiring $1 / 3$ of the holding. \\
\hline 2001 & Enron & The bankruptcy of Enron. \\
\hline 2003 & Enron, Prisma Energy & Creation of Prisma Energy, which takes over Enron's shares. \\
\hline 2006 & $\begin{array}{l}\text { Prisma Energy, Ashmore } \\
\text { Energy International }\end{array}$ & Ashmore Energy International Ltda buys Prisma Energy. \\
\hline 2006 & $\begin{array}{l}\text { Transredes, Ashmore Energy } \\
\text { International, Shell }\end{array}$ & The Bolivian government nationalises Transredes. \\
\hline 2007 & Ashmore Energy International, Shell & Ashmore buys shares of TBG, acquiring $4 \%$ of the company. \\
\hline 2008 & Transredes, Shell and Ashmore & $\begin{array}{l}\text { Shell and Ashmore sign agreements to transfer the shares owned by Transredes } \\
\text { to the Bolivian government, via the state-owned company YPFB. }\end{array}$ \\
\hline 2012 & Shell, BearGás Participações Ltda & Shell's shares are transferred to its subsidiary BearGás Participações Ltda. \\
\hline 2012 & $\begin{array}{l}\text { Ashmore Energy International, } \\
\text { BearGás Participações Ltda }\end{array}$ & BearGás Participações Ltda acquires Ashmore's shares of TBG. \\
\hline 2012 & $\begin{array}{l}\text { BearGás Participações Ltda, GTB-TBG } \\
\text { Holding SARL, EIG Global Partners }\end{array}$ & $\begin{array}{l}\text { Bear Gás Participações Ltda sells its shares to the GTB-TBG Holdings S.A.R.L., } \\
\text { a company owned by the EIG - Global Energy Partners. }\end{array}$ \\
\hline 2013 & BG, El Paso, BBPP, EIG Global Partners & $\begin{array}{l}\text { BG and EL Paso sell their shares of BBPP to the GTB-TBG Holdings S.A.R.L. } \\
\text { (owned by the EIG Global Partners). }\end{array}$ \\
\hline
\end{tabular}

Source: Elaborated by the authors.

According to the interviewees' perception, shareholders had different expectations and perspectives, both in terms of the time horizon and the focus of operations. These divergences were particularly expressive in the early stages of society, when many conflicts of interest emerged. As a result, these differences and attempts at alignment were configured as one of the main agendas of the company's Board of Directors' meetings, reflecting the role of the body in addition to the typical strategy and control functions. Thus, in the opinion of the interviewees, in the early years of the company, the board acted to mediate many corporate conflicts, a role that they considered effective and capable of allowing and promoting high-level discussions, without coercion from the block holders. The search for synergies with other businesses, an important feature in large oil companies, provoked public debates among the shareholders, which were mediated by the Brazilian regulatory body, the National Petroleum Agency (ANP), from 2000 to 2002. During this period, the volumes transported were lower than those contracted by Petrobras, the company that remunerated TBG for transportation services. Therefore, there was contracted 
and unused capacity in the pipeline, information that BG and Enron (shareholders) were aware of, and they were interested in contracting it. As a consequence of negotiations and ANP's mediation, TBG signed a short-term contract based on capacity with Enron and BG, respectively.

The interviewees mentioned that this episode generated tensions with TBG's Board of Directors, with separation of votes and confrontation of legal opinions. Probably the shareholders considered their positions in the business as a way of diversifying their activities and identifying opportunities in a market that lacks regulation. The business of transporting natural gas in isolation, although profitable, did not represent value to the shareholders' strategies since, as large oil companies, they had a portfolio of assets to be managed.

It is possible to observe a maturity in the company's governance after the difficulties of the first years. The largest investments were already made, the minority shareholders were no longer interested in contracting transportation, and TBG was not interested in increasing transportation capacity. At this moment, the shareholders were aligned in a more financially driven perspective.

Indeed, with the exit of Shell, Enron and El Paso, the remaining shareholders had a profile more financial than operational. For one of the interviewees: "the shareholders with expertise in the business were important at the beginning of the operations, with technical suggestions that resulted in savings. In the next stage, as the company was already consolidated (structurally organised; processes and technology defined and mastered; robust program of preventive maintenance), changing the shareholders' profile did not affect its management".

The description of the events in the study did not show the occurrence of the typical governance problems observed in closed companies, caused by practices of minority shareholder oppression. However, many changes occurred, and among the original shareholders, the only one who remained in the company was the controller, Gaspetro, who transferred its shares to Petrobras Logística S.A. in 2015.

\section{DISCUSSION AND ANALYSIS}

For TBG, because it was created based on project finance approved with financing agencies such as IADB and IBRD, the transparency on the shareholders' roles, the limits of the managers' responsibilities, and the functioning of the governance mechanisms were defined in its origin. This characteristic makes TBG different from most closed companies, which are driven to implement good governance practices as there is an increasing interest in professionalising management and having access to capital market. For TBG, the research showed that there was a high adherence to the recommendations of the Instituto Brasileiro de Governança Corporativa (IBGC) (Brazilian Institute of Corporate Governance), published in 2014 to guide closed companies.

The longitudinal study showed that the most important contracts for the operation of the company (Shareholders' Agreements and Contracts on Gas Transportation) were built based on a wide negotiation between the shareholders. The resources used to discuss the clauses and safeguards in these documents aimed to mitigate the risks to the parties involved and were crucial for the preservation of the interests of shareholders and project financiers in the later events.

These prior negotiations proved to be fundamental for the stability of the business, considering the shareholders' concern with possible risks to their brands in the face of operational failures or other negative events, which would also impact the situation of their parent companies. As Sabatino and Wolf (2010) argue in their analysis on the risks companies run because of their subsidiaries' performance, it is critical that the subsidiary's governance system is based on principles that are clear and consistent with the shareholders' long-term global strategy. As a result, each shareholder brings their particular concern to the agreement, increasing the requirement for proper prior alignment.

For Moll (2005), a large part of the conflicts between shareholders in closed companies are caused by the lack of adequate planning before the creation of the company, lack of legal sophistication, and difficulty in predicting future situations. In the case of TBG, because it involved large multinational companies, with skilled legal departments, and contracts widely discussed, it is possible that larger conflicts were avoided in the events presented below. 
An important factor to consider as an enforcement mechanism regarding the agreements was the financing structure. Because it was made via project finance, the guarantees were the project's receivables, which were established in the contracts of gas transportation (the company's only source of revenue).

From the minority shareholders' point of view, the transactions involving TBG demanded strict contractual protection for many reasons. First, due to the uncertainties related to the development of the market and its regulation. Second, because of the presence of a controlling shareholder integrated into the operational chain and with a dominant position. Therefore, the risk of manipulation in the asymmetries of information was present. Third, the specificity of the asset creates a long-term bond between the service provider, TBG and its contractor, Petrobras. In this case, the contractor held $100 \%$ of the shares of TBG's controlling shareholder (Gaspetro). According to the transaction costs theory, the combination of these three factors creates an environment conducive to opportunistic behaviour, something that was not identified in the research. Possibly, the rigour in the elaboration of the contracts has helped to avoid this type of situation. As recommended by Bennedsen and Wolfenzon (2000), the existence of a second shareholder with relevant participation, in line with that advocated by Pagano and Roell (1998), has proven to be an effective practice to preserve the interests of minority shareholders.

According to interviewees, there was no indication of disregard to rules or oppressive practices on the part of the controlling shareholder. Despite several changes in shareholders configuration across time. The conclusion is that the motivation for leaving the business was external to the company, so they are not related to its governance. Reasons such as portfolio positioning to align with global strategies, an evolution of the political environment in Bolivia and regulatory in Brazil, were decisive for the changes in shareholding structure over time.

Hetherington and Dooley (1977) argue that the lack of liquidity of minority shares is a potential condition for an oppressive stance of the controlling shareholder. By the number of transactions involving minority shareholders, however, it is possible to say that the TBG shares were quite liquid since it was not difficult to find investors interested in the business. Even without having access to the TBG Shareholders' Agreement, it is possible to presume that the terms of the share sale and exit rights were well-defined.

It is interesting to note the importance of a well-defined controller in the case of subsidiaries created to fulfil a specific purpose (Baek, 2003), considering the attempts to diversify the company and the tensions observed within the Board of Directors. In both situations, the controller's actions to avoid the diversification of activities and the signing of contracts not foreseen in the initial design of the business model, contributed so TBG remained faithful to the purpose for which it was created, honouring its debts and being profitable for the investors.

Box 2 resumes the critical elements listed in the theoretical framework and compares the origins of the main governance problems and the situation observed in the TBG's longitudinal study. 
Box 2

Association between the critical elements in the theories and the situations observed in the TBG'slongitudinal study

\begin{tabular}{|c|c|c|c|}
\hline Author & $\begin{array}{l}\text { Origins of the } \\
\text { governance problems }\end{array}$ & Description & Observed situation \\
\hline Moll (2005) & $\begin{array}{c}\text { Lack of ex-ante } \\
\text { planning. }\end{array}$ & $\begin{array}{l}\text { Lack of knowledge about the legislation } \\
\text { and the business may lead to unbalanced } \\
\text { contracts. It is recommended to foresee } \\
\text { events that may generate conflict and } \\
\text { design safeguards to protect minority } \\
\text { shareholders. }\end{array}$ & $\begin{array}{l}\text { The exhaustive discussion of the } \\
\text { Shareholders' Agreements and contracts, } \\
\text { in addition to the size of the shareholders } \\
\text { probably prevented conflicts and minority } \\
\text { oppression. }\end{array}$ \\
\hline Moll (2005) & $\begin{array}{l}\text { Uncertainty regarding } \\
\text { the exit rights of minority } \\
\text { shareholders. }\end{array}$ & $\begin{array}{l}\text { Lack of clear definition of exit rights in } \\
\text { the Shareholders' Agreement may lead to } \\
\text { oppressive behaviour from the controlling } \\
\text { shareholder. }\end{array}$ & $\begin{array}{l}\text { The high number of changes of minority } \\
\text { shareholders indicate that the conditions } \\
\text { were clear. }\end{array}$ \\
\hline $\begin{array}{l}\text { Nagar, Petroni and } \\
\text { Wolfenzon (2009); } \\
\text { Bennedsen and } \\
\text { Wolfenzon (2000) }\end{array}$ & $\begin{array}{l}\text { The principle of } \\
\text { 'majority rule.' }\end{array}$ & $\begin{array}{l}\text { In order to avoid that the controlling } \\
\text { shareholder makes decisions based on self- } \\
\text { interest, it is recommended that minority } \\
\text { shareholders have veto power in matters } \\
\text { that affect their interest. }\end{array}$ & $\begin{array}{l}\text { The most important contracts (transactions } \\
\text { among related parties) were discussed in } \\
\text { the Shareholders' Meeting, where minority } \\
\text { shareholders had veto power. }\end{array}$ \\
\hline Baek (2003) & $\begin{array}{l}\text { Lack of alignment } \\
\text { between a parent } \\
\text { company and subsidiary. }\end{array}$ & $\begin{array}{l}\text { In the case of the subsidiaries in which there } \\
\text { is no defined controller, there is a higher } \\
\text { risk that the subsidiary deviates from the } \\
\text { goal to which it was created. }\end{array}$ & $\begin{array}{l}\text { The existence of a defined controller } \\
\text { prevented the subsidiary from deviating } \\
\text { from the purpose to which it was created. }\end{array}$ \\
\hline
\end{tabular}

Source: Elaborated by the authors.

Even though the synergies expected by the minority shareholders have not been fully realised for other reasons not investigated in this study, it is possible to argue that TBG represented a gateway for foreign companies in the Brazilian oil and gas sector. The interviews carried out indicate that, from the perspective of Petrobras, the association with large foreign groups in a business partnership sharing decision has provided maturity to the company regarding governance and relationship with shareholders.

The interviews showed TBG gained its own identity, built from the shareholders' experiences, the qualities they brought from the private businesses (agility, efficiency, cost control, discussion of budgets to exhaustion), and expertise of the majority shareholder, particularly regarding the knowledge of the Brazilian market, relationship with governmental agencies and institutions, understanding of regional cultural diversity, and capacity for mobilisation.

Considering the universe of Brazilian closed companies and the characteristics of TBG such as clarity of the shareholders' and management's roles; maturity of control mechanisms; and degree of transparency, it is possible to say that TBG is at a higher level organisation in terms of governance, which is also acknowledged by the Associação Brasileira das Companhias Abertas (Abrasca) (Brazilian Association of Public Companies). For seven years, ABRASCA considered TBG's Annual Report the best of Brazil in the category closed company. In 2010, for the fourth time, TBG was awarded with the "Transparency Trophy" for the best publication of accounting demonstration in the group of closed companies granted by Associação Nacional dos Executivos de Finanças, Administração e Contabilidade (ANEFAC) (Brazilian Association of Finance, Administration and Accounting Executives). 


\section{CONCLUSIONS}

This study aimed to contribute to a new perspective of the analysis of corporate governance practices, based on longitudinal studies, having as reference the role played by the partners in the changes of ownership and its reflexes in the attributions of the board of directors. This analytical perspective allowed to observe that not only governance solutions and configurations to deal with agency problems must be re-evaluated, but also the nature of the principal's interests and their relationship in the ownership structure.

As in the study by Filatotchev et al. (2006), it is possible to observe different stages in the company's governance history and identify the main problems in each stage.

In line with previous studies that similarly followed a longitudinal approach to analyze changes in the company's governance in its life cycle (Esqueda \& O'Connor, 2020; Filatotchev et al., 2006; O'Connor \& Byrne, 2015a) we observed different stages in the company's governance history, associated with different problems at each stage.If initially, the controller is supported by deep discussions to align interests, over time, with the arrival and exit of other shareholders, the main nature of the ownership (strategic or financial) becomes more evident. At this point, the tacit trust building proved to be a differential in the joint venture's sustainability.

The results of the study point to a temporal variation in the agency problem, be it a type I agency problem - between the shareholders and managers - or type II-among the shareholders. This is the predominant situation in the situation studied, and it is diffused in emerging countries. Also, as a closed company, TBG was less influenced by external control mechanisms, especially the pressure of stock markets. Thus, the internal conflicts and the interests of shareholders are stressed over time.

As shown in TBG's study, the variable 'power' can also be highlighted, as discussed by Licht (2011) to influence the business configuration. The various shareholders had distinct interests, mostly unrelated to maximising business value, which brings complexity to agreements aimed at defining the company's strategies and priorities and exacerbating the potential for principalprincipal conflicts. The methodology, based on a longitudinal study, made it possible to highlight how shareholders' interests and the governance arrangements change, indicating the need for further studies that consider these variations over time. The results also suggest the need for new proposals for corporate governance guidelines that consider that agency problem, the nature and goals of shareholders and managers, risk propensity, and asymmetries of information between the parties, are subject to variations over time.

It should be considered, as a possible limitation of the study, that the choice of TBG for analysis brought the implicit bias of the participation of a state-owned majority shareholder with the capacity to risk the initial risks of the enterprise and to offer demand. In this sense, the presence of Petrobras as the controlling shareholder of TBG may have changed the attractiveness of the business and changed the parameters of participation in the shareholding structure of minority shareholders, although the presence of a controller may bring additional risk of expropriation and tunneling of minority shareholders. However, as the case of a similar investment in other companies shows, this guarantee does not mean the absence of challenges or security in the results. As the case of Sete Brasil shows, a company created in 2010 by Petrobras and public and private partners to facilitate the production of oil rigs (Gradilone \& Galembeck, 2016), state control and commitment to demand does not detract from the importance of quality governance practices. As argued by Young, Peng, Ahlstrom and Bruton (2002, p. E-5), "In emerging economies, state ownership and the control of corporate assets are positively associated with an increase in the propensity and magnitude of the principal-principal agency".

Other limitations that may have influenced the study are the adoption of a qualitative research based on bibliographical review and field research may not have exhausted the possible types of issues that result in governance problems in closed companies, and the sample of respondents by former managers appointed by the controlling shareholder. Of the 17 interviewees, only three were appointed by the minority. This restriction is because the controlling shareholder is responsible for appointing the three members of the Board of Executive Officers and a majority of the representatives of the Board of Directors. Although the analysis was conducted with as much impartiality as possible, this numerical superiority may have influenced the analysis. Despite these limitations, in advancing a path that has been little explored in the studies on governance with an emphasis on the history of the configurations and agreements, it is expected that this research contributes and stimulates a new dimension of analysis on governance issues. 


\section{REFERENCES}

Aguilera, R. V., Florackis, C., \& Kim, H. (2016). Advancing the corporate governance research agenda. Corporate Governance: An International Review, 24(3), 172-180.

Aguilera, R. V., \& Jackson, G. (2003). The cross-national diversity of corporate governance: Dimensions and determinants. Academy of management Review, 28(3), 447-465.

Baek, H. Y. (2003). Parent-Affilate Agency Conflicts and Foreign Entry Mode Choice. Multinational Business Review, 11(2), 75-98.

Belak, J. (2016). Management and governance: organizational culture in relation to enterprise life cycle. Kybernetes, 45(4), 680-698.

Bennedsen, M., \& Wolfenzon, D. (2000). The balance of power in closely held corporations. Journal of financial economics, 58(1-2), 113-139.

Bongjin, K. (2002, August). Adaptation of governance mechanisms to deregulation: a longitudinal study of the US banking industry. Academy of Management Proceedings, 2002(1), D1-D6.

Costa, A. C. (2012). Sete Brasil, a nova empresa da Petrobras. Revista Exame. Retrived from https://exame.com/negocios/ sete-brasil-a-nova-empresa-da-petrobras/

Cuevas-Rodríguez, G., Gomez-Mejia, L. R., \& Wiseman, R. M. (2012). Has agency theory run its course? Making the theory more flexible to inform the management of reward systems. Corporate Governance: An International Review, 20(6), 526-546.

Esqueda, O. A., \& O'Connor, T. (2020). Corporate governance and life cycles in emerging markets. Research in International Business and Finance, 51, 101077.

Filatotchev, I., Toms, S., \& Wright, M. (2006). The firm's strategic dynamics and corporate governance life-cycle. International Journal of Managerial Finance, 2(4), 256-279.

Filatotchev, I., \& Wright, M. (2017). Methodological issues in governance research: An editor's perspective. Corporate Governance: An International Review, 25(6), 454-460.

Fusch, P. I., \& Ness, L. R. (2015). Are we there yet? Data saturation in qualitative research. The qualitative report, 20(9), 1408-1416.

Gradilone, C.; Galembeck, F. (2016). Impacto profundo. Isto é Dinheiro. Retrived from https://www.istoedinheiro.com.br/noticias/ financas/20160506/impacto-profundo/370206

Hetherington, J. A., \& Dooley, M. P. (1977). Illiquidity and exploitation: A proposed statutory solution to the remaining close corporation problem. Virginia Law Review, 63(1), 1-75.

Huse, M. (Ed.). (2008). The value creating board: Corporate governance and organizational behaviour. Abingdon, UK: Routledge.

Jensen, M. C. (2010). Value maximization, stakeholder theory, and the corporate objective function. Journal of applied corporate finance, 22(1), 32-42.

Jensen, M. C., \& Meckling, W. H. (1976). Theory of the firm: Managerial behavior, agency costs and ownership structure. Journal of financial economics, 3(4), 305-360.

Law, P. L., \& De Franco, N. (1998). International Gas Trade: The BoliviaBrazil Gas Pipeline. Retrived from http://www-wds.worldbank.org/
external/default/WDSContentServer/WDSP/IB/1999/08/15/00000 9265_3980901110022/Rendered/PDF/multiOpage.pdf

Licht, A. N. (2011). Corporate Governance. In G. Caprio (Ed.), Encyclopedia of Financial Globalization. Oxford, UK: Elsevier.

Miller, D., \& Friesen, P. H. (1984). A longitudinal study of the corporate life cycle. Management science, 30(10), 1161-1183.

Mitsuhashi, H., Shane, S., \& Sine, W. D. (2008). Organization governance form in franchising: efficient contracting or organizational momentum?. Strategic Management Journal, 29(10), 1127-1136.

Moll, D. K. (2005). Minority Oppression \& (and) the Limited Liability Company: Learning (Or Not) from Close Corporation History. Wake Forest L. Rev., 40, 883.

Nagar, V., Petroni, K., \& Wolfenzon, D. (2009). Governance problems in close corporations. New York, NY: University Stern School of Business. Retrived from http://www.insead. edu/facultyresearch/areas/accounting/events/documents/ GovernanceProblemsinCloseCorporations.pdf

O'Connor, T., \& Byrne, J. (2015a). Governance and the corporate life-cycle. International Journal of Managerial Finance, 11(1), 23-43.

O'Connor, T., \& Byrne, J. (2015b). When does corporate governance matter? Evidence from across the corporate life-cycle. Managerial Finance, 41(7), 673-691.

Pagano, M., \& Röell, A. (1998). The choice of stock ownership structure: Agency costs, monitoring, and the decision to go public. The Quarterly Journal of Economics, 113(1), 187-225.

Sabatino, T. J., \& Wol, S. E. (2010). Subsidiary Governance: What It Is, Why It Matters and How to Build a Good System. The Corporate Governance Advisor, 18(3), 5-9.

Shen, W. (2003). The dynamics of the CEO-board relationship: An evolutionary perspective. Academy of Management Review, 28(3), 466-476.

Shleifer, A., \& Vishny, R. W. (1997). A survey of corporate governance. The journal of finance, 52(2), 737-783.

Thiry-Cherques, H. R. (2009). Saturação em pesquisa qualitativa: estimativa empírica de dimensionamento. Revista PMKT, 3(2), 20-27.

Thomsen, S. (2004). Corporate values and corporate governance. Corporate Governance: The international journal of business in society, 4(4), 29-46.

Torres, E. T., Filho. (2002). O gasoduto Brasil-Bolívia: impactos econômicos e desafios de mercado. Revista do BNDES, 9(17), 99-116.

Walsh, J. P., \& Seward, J. K. (1990). On the efficiency of internal and external corporate control mechanisms. Academy of management review, 15(3), 421-458.

Weitzel, U., \& McCarthy, K. J. (2011). Theory and evidence on mergers and acquisitions by small and medium enterprises. International Journal of Entrepreneurship and Innovation Management, 14(2-3), 248-275.

Young, M., Peng, M. W., Ahlstrom, D., \& Bruton, G. (2002). Governing the corporation in emerging economies: a principal-principal agency perspective. Academy of Management Best Papers Proceedings, 2002(1), E1-E6. 
Fabricio Bomtempo Oliveira

ORCID: https://orcid.org/0000-0002-2785-2903

Master in Business Administration at Fundação Getulio Vargas (FGV). E-mail: f.bomtempo@ hotmail.com

Joaquim Rubens Fontes Filho

ORCID: https://orcid.org/0000-0001-6377-1185

Ph.D. in Business Administration at Fundação Getulio Vargas (FGV); Senior associate professor at FGV EBAPE. E-mail: E-mail: Joaquim.rubens@fgv.br 